Western University Scholarship@Western

Electrical and Computer Engineering Publications Electrical and Computer Engineering Department

$8-2013$

\title{
A Meta-Analysis of Critical Success Factors Affecting Mobile Learning
}

Luiz Fernando Capretz

University of Western Ontario, lcapretz@uwo.ca

Muasaad Alrasheedi

Western University, malrash@uwo.ca

Follow this and additional works at: https://ir.lib.uwo.ca/electricalpub

Part of the Education Commons, and the Engineering Commons

Citation of this paper:

Capretz, Luiz Fernando and Alrasheedi, Muasaad, "A Meta-Analysis of Critical Success Factors Affecting Mobile Learning" (2013). Electrical and Computer Engineering Publications. 18.

https://ir.lib.uwo.ca/electricalpub/18 


\section{A Meta-analysis of Critical Success Factors Affecting Mobile Learning}

\author{
Muasaad Alrasheedi \\ Department of Electrical and Computer Engineering \\ University of Western Ontario \\ London, ON, Canada \\ malrash@uwo.ca
}

\author{
Luiz Fernando Capretz \\ Department of Electrical and Computer Engineering \\ University of Western Ontario \\ London, ON, Canada \\ lcapretz@uwo.ca
}

\begin{abstract}
Considering the popularity and ubiquitous nature of mobile phones, the acceptance of $\mathrm{m}$-Learning in educational institutions is limited. While several studies have reviewed mLearning platforms, different settings and contexts make it difficult to collate these studies and discover the key factors for the successful adoption of m-Learning platform. This study uses meta-analysis technique to compare results from multiple studies assessing the critical $\mathrm{m}$-Learning success factors. We find that learners perceive collaboration opportunities and anytimeanywhere learning possibility as the key benefits of m-Learning. Further, good content presented in a user friendly way is a primary expectation from an $\mathrm{m}$-Learning application.
\end{abstract}

Keywords-m-learning, m-education, higher education, critical success factors.

\section{INTRODUCTION}

Mobile Learning is gaining increasing attention both in terms of learning in general as well as in terms of designing mobile systems and services for learners and educators. The growing interest in the field has prompted researchers to study the mobile learning phenomenon scientifically. However, it is difficult to collate the research due to the multitude of definitions of the m-learning concept [1].

Further, the mobile learning technology is entirely dependent on the interaction between humans and machines. Hence, the research focus should not be limited to the capability of mobile devices and applications and must also extend to the impact of using the mobile platform in learning in different contexts as well as the factors affecting the user experience from the point of views of learners, educators, and university management [2].

Statistics show that less than a decade back, in 2004, 70 percent of the people in the world had never used a telephone [3]. In contrast to this, the World Bank reported that in 2012 close of $75 \%$ of the world, including the developing world, have an access to a mobile phone [4]. This not only shows the immense success of the technology itself, but also the fact that people are aware of the multitude of benefits of the mobile phones. Also the mobile devices have become much more capable with the addition to several sophisticated of features enhancing their usability in several different ways.

All these factors should mean that the success of $\mathrm{m}$ Learning should be a foregone conclusion. However, this is not the case as not many institutions have adopted the practice of
m-Learning as a mainstream platform for imparting educations. Studies have found that learners are more like regular consumers and mere technical superiority is not sufficient for success of mobile learning. The new platform will be additionally judges on the basis of functional, emotional, epistemic, conditional, and social values that the learners are expected to gain from using the learning platform. [5] Researchers have conducted several pilot studies to understand the issues in m-Learning especially in the higher education sector in the area of engineering. The learners from pursuing engineering studies are considered to be sufficiently old and technically competent to understand and exploit the mobile phone interface for educational purposes [6].

The results of one such research showed that while most learners from pursuing higher education in the area of engineering already own mobile phones and understand their usage intimately. The learners are completely in favor of using $\mathrm{m}$-Learning as a learning platform as they believe that this will enhance their educational experience. The most attractive features of m-Learning is the possibility of self-learning at the learner's pace, place and time. However, the preference of the choice of devices for m-Learning tended to be towards notebooks and palm top type smart phones rather than the traditional mobile handsets. As this would predictably increase the cost of education, so the learners were also interested in knowing how the learning costs could be reduced or avoided altogether. In fact the price factor was deemed to be the major barrier to the adoption of $\mathrm{m}$-Learning in education sector, from the learner's perspective [7].

While the success of m-Learning in higher education was highly contextual based on the individual research, some characteristics were seen to be similar and could be developed into a framework for assessment of success of m-Learning. In [8], one such conceptual framework was proposed. The factors used to assess the success of $\mathrm{m}$-Learning in this framework were learning experience, learning contexts and design issues. This paper is uses similar factors in an effort to collate the critical success factors that affect the mobile-learning adoption and acceptance, based on the evidence from multiple studies.

This paper is structured as follows. Section II introduces the mobile learning and what the term entails. Section III discusses the critical factors for its success in the educational sector based on prior studies. Section IV discusses the mode of assessing the critical success factor of mobile learning based on 
current studies. Section V presents a meta-analysis of the critical success factors of mobile learning from current studies. Section VI presents the result and corresponding discussion while Section VII presents the conclusions and future implications of the research.

\section{MOBILE LEARNING}

Mobile devices offer the flexibility of mobility in learning the unique feature of the M-learning platform. The term mobility here refers to the possibility of having flexibility in terms of time, place, pace and space that is not achievable when using non-mobile versions of devices [2]. Theoretically speaking, mobile learning offers the learners the possibility of learning anywhere and everywhere. However, users must understand that the term 'everywhere' is relative due to issues like connectivity restrictions as well as safety restrictions [9].

In addition to mobility, mobile-learning platform also offers learners the chance to interact with fellow students and educators from different locations even when they are not in a formal classroom. These two characteristics make mobile learning different from other existing technology-based and non-technology based learning platforms, including e-learning. In fact, mobile phones are considered to be highly effective as devices of learning provided that the technology and learning goals match [10].

Mobile learning allows learners to manage the content, scope and space of their learning. Learners also have control over the time they access the learning materials and the place where they access the learning materials. Professionals can use mobile phones for just-in-time learning where learners can apply the information instantly rather than the usual process of gaining the knowledge first, store it in their minds and then use the information practically at a later date. Mobile learning also has the additional advantage to engaging learners in far-flung locations that do not have access to schools, teachers, or libraries [9]. In other words, the concept of mobility does not only refer to the mobility of the student but also the mobility of content. Again the mobility of content is not confined in terms of spatial shift, but also factors in the reduced processing time and the lack of physical boundaries. Both these factors would push the envelope in terms of learning methods as well as information access [12].

However, despite the immense penetration and world-wise popularity of the usage of mobile technology, its adoption in the education section, especially higher education, has been slow. Several researchers attribute this anomaly to educators not having sufficient understanding of how to use the technology to enhance learning process. Several educators are also uncomfortable with the technology itself, despite being presented with documented proofs from research studies showing positive inputs from students and other educators regarding the use of mobile learning. Other reasons for the slow adoption of mobile technology in education are the limitations of the technology itself as well as concerns regarding security and privacy [13].

\section{CRITICAL Success Factors For The AdOPTION OF MOBILE LEARNING}

The successful adoption of mobile learning, especially in higher education, is dependent on the union of several factors. The factors that compel an individual to accept m-learning for educational purposes are still unclear and are a core focus for research in this field. However, researches agree that these factors would be a combination of technology, processes and pedagogical approaches [14].

Naismith and Corlett [15] conducted a detailed study of the literature pertaining to $\mathrm{m}$-Learning, published at various mobile learning conferences between 2002 and 2005. They found that while different researchers found a diverse set of factors responsible for the success and failure of m-Learning projects, five of the factors were a part of every m-learning literature technology availability, support of the concerned institution, network connectivity, assimilation with study curriculum or student experience or real life, and technology ownership by learners [15]. The study was considered as to be a basic information source for researchers as well as implementers of mobile learning.

However, it must be considered that the above study is over six years old. During this period, the penetration of mobile devices in the world, including people from remote areas and communities (as shown in the previous section) has exploded. People are no longer apprehensive of the technology and mobile usage is a part of life for over three-quarters of the world population. Thus there is a need to re-evaluate the critical success factors in light of the present state of adoption of mobile technology among the general population. The present study is an effort in this direction.

\section{ASSESSING CRITICAL SUCCESS FACTORS FROM CURRENT STUDIES}

A recent UNESCO report on mobile learning considers the following factors as essential conditions for successful adoption of mobile learning: affordability, leadership, content, support from educators and parents, defining m-learning goals, recognition of informal learning, and defining target learner groups for mobile learning [16]. However, UNESCO too agrees that there is no common set of success factors that will suit every learning environment, all the factors are not yet known as well as points out that the factors discussed above must be tailored for every context [16].

UNESCO has conducted such studies in different countries throughout Asia and Africa. The success factors essentially remain the same, though Asian initiatives in mobile learning would be more successful if the government policies in areas such as funding and resources support mobile learning. This is in fact the main driver for the success of mobile learning initiatives in the education sector, especially in higher education settings. Another critical success factor in the Asian countries is the availability of affordable internet-ready mobile devices with appropriate network connectivity [17]. 


\section{Meta ANALYSIS Of CRITICAL SUCCESS FACTORS}

Meta analysis is essentially a quantitative literature review method as opposed to the traditional narrative literature review. Meta analysis makes use of a set of statistical procedures to summarize a collection of previously reported statistical findings from research papers that investigate the same or similar research questions [18].

This paper presents a meta-analysis of the critical success factors or CSFs (used henceforth throughout the paper) affecting mobile learning. The study of mobile learning has not as yet followed a specific research pattern hence there is no particular research question that will be common to all the research studies. Hence, the present paper uses the critical success factors discussed in sections III and IV as the set of basic variables. The presence of these variables has been detected in the review studies conducted by researchers on the existing mobile learning projects across the world. Table I lists the CSFs and their presence in various studies on mobile learning across the world. The initial source for CSFs in the area of mobile learning was [15]. The background for assessment of CSFs in current studies was gained from [19].

The total number of studies used while making the Table I is 19. In order to conduct the meta-analysis of the above data, first only those critical success factors are considered that have been evaluated in six or more studies. The reason for selecting the CSFs based on their presence in at least six studies is because this will provide sufficient statistics for the metaanalysis that is to be conducted in the later section.

A detailed analysis of studies under consideration shows that there are nine such factors - user friendly design, technical competence, learner community development, learner's perceptions, content, ownership, accessibility, choice of mobile devices, and cross platform capability (shown in italics, both regular and bold fonts, in the Table I below).

TABLE I. CSFS IN VARIOUS M-LEARNING STUDIES

\begin{tabular}{|c|c|c|}
\hline \multirow[b]{2}{*}{ CSFs } & \multicolumn{2}{|c|}{ Appearance in Various Studies } \\
\hline & Author References & $\begin{array}{c}\text { No. of } \\
\text { Citations }\end{array}$ \\
\hline Availability & {$[20][21][22]$} & 3 \\
\hline Accesibility & $\begin{array}{l}{[21][22][23][24][25][26]} \\
{[27][28]}\end{array}$ & 8 \\
\hline Affordability & {$[21][26]$} & 2 \\
\hline Internet Access & {$[25][28][29][30]$} & 4 \\
\hline Connectivity & {$[22][24][28]$} & 3 \\
\hline $\begin{array}{l}\text { Choice of Mobile } \\
\text { Devices }\end{array}$ & $\begin{array}{l}{[21][27][28][31][32][33]} \\
{[34]}\end{array}$ & 7 \\
\hline Web 2.0 Software & {$[21][31][34]$} & 3 \\
\hline $\begin{array}{ll}\text { Cross } & \text { Platform } \\
\text { Capability } & \\
\end{array}$ & $\begin{array}{l}{[20][22][28][31][32][32]} \\
{[34]}\end{array}$ & 7 \\
\hline Ownership & 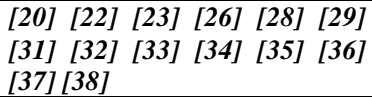 & 14 \\
\hline Institutional Support & [34] & 1 \\
\hline Content & {$[20][22][25][26][32][36]$} & 6 \\
\hline
\end{tabular}

\begin{tabular}{|c|c|c|}
\hline \multirow[b]{2}{*}{ CSFs } & \multicolumn{2}{|c|}{ Appearance in Various Studies } \\
\hline & Author References & $\begin{array}{l}\text { No. of } \\
\text { Citations }\end{array}$ \\
\hline $\begin{array}{l}\text { Assimilation with } \\
\text { Curriculum }\end{array}$ & {$[22][25][26]$} & 3 \\
\hline Educators' Perspective & {$[21][26][34]$} & 3 \\
\hline Learner's Perceptions & $\begin{array}{l}{\left[\begin{array}{llllll}20] & {[21]} & {[22]} & {[23]} & {[24]} & {[26]} \\
{[28]} & {[29]} & {[31]} & {[32]} & {[33]} & {[34]} \\
{[35]} & {[36]} & {[37]}\end{array}\right.}\end{array}$ & 15 \\
\hline $\begin{array}{l}\text { Learning Community } \\
\text { Development }\end{array}$ & $\begin{array}{l}{[20][21]\left[\begin{array}{llll}{[22]} & {[24]} & {[25]} & {[28]} \\
{[33][34]}\end{array}\right.}\end{array}$ & 8 \\
\hline $\begin{array}{l}\text { Develop Assessment } \\
\text { techniques }\end{array}$ & {$[21]$} & 1 \\
\hline Faculty Commitment & [21] [25] [26] [34] [35] & 5 \\
\hline Users' Feedback & {$[21][23][25][26][34]$} & 5 \\
\hline $\begin{array}{l}\text { Technical Competence } \\
\text { of Instructors }\end{array}$ & {$[25]$} & 1 \\
\hline $\begin{array}{l}\text { Technical Competence } \\
\text { of Students }\end{array}$ & $\begin{array}{l}{[20][21][23][25][28][30]} \\
{[31][32][33][34][36]}\end{array}$ & 11 \\
\hline $\begin{array}{l}\text { User Friendly Design } \\
\text { of Content }\end{array}$ & $\begin{array}{l}{[20][21][22][23][29][30]} \\
{[32][33][35][36][37]}\end{array}$ & 11 \\
\hline
\end{tabular}

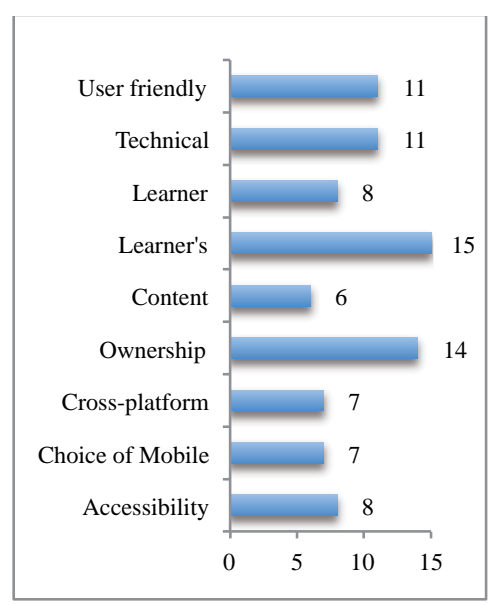

Fig. 1. Plot of CSFs versus No. of Citations

Fig. 1 shows a simple plot of the nine CSFs and the corresponding number of studies where each has been cited. Further analysis of the papers was conducted and it was found that there was no enough statistical data available for three of the CSFs - accessibility, choice of mobile devices, and cross platform capability. Hence, only six CSFs were shortlisted (shown in bold font in Table I) for a cross-sectional analysis across multiple studies - user friendly design, technical competence, learner community development, learner's perceptions, content, and ownership.

The focus was now shifted to the papers to find out if sufficient statistical was available for analysis. It was found that only 9 of the 18 studies had similar statistical information that could be used for conducting meta-analysis [20] [24] [26] [28] [30] [32] [35] [36] [37]. The remaining nine 10 studies [21] [22] [23] [25] [27] [29] [31] [33] [34] [38] were discarded as they either used very different statistical measurements or did not have sufficient raw data required for analysis. 
As can be seen from the Table II the CSF 'Learner's perceptions' is present in all the nine studies. A glance at the Table I also show that this CSF is present in the maximum number of studies (15 of 18 studies under initial consideration). A review of all the papers shows that learner's perception actually refers to whether the learners would consider opting for mobile-learning in future based on their current experiences. As the success of mobile-learning directly refers to the continued usage of mobile-learning platform, this CSF becomes even more important. In fact in several studies, learner's perception was actually correlated with other CSFs as a means for judging the success of mobile learning in a particular institution.

The present meta-analysis also uses learner's perception as a means of assessing the success of m-Learning in various institutions i.e. a dependent variable. The individual correlations are not available for some of the nine studies hence the meta-analysis consisted of aggregating the mean values of the remaining five CSFs for these studies and then correlating them with the learner's perception. Microsoft excel was used as a means of performing this operation. The meta-analysis conducted in [39] is the basis for the present study. The metaanalysis results are shown in Table III.

TABLE II. CSF STATISTICS IN SHORTLISTED StUdies

\begin{tabular}{|c|c|c|c|c|c|c|}
\hline \multirow[b]{2}{*}{$\begin{array}{l}\text { Stati } \\
\text { stics }\end{array}$} & \multicolumn{6}{|c|}{ Critical Success Factors } \\
\hline & $\begin{array}{c}\text { User } \\
\text { Friendly } \\
\text { Design } \\
\end{array}$ & $\begin{array}{c}\text { Technical } \\
\text { Competen } \\
\text { ce } \\
\end{array}$ & $\begin{array}{c}\text { Learner } \\
\text { Community } \\
\text { Development }\end{array}$ & $\begin{array}{c}\text { Learner } \\
\text { Percepti } \\
\text { ons }\end{array}$ & $\begin{array}{c}\text { Conte } \\
n t\end{array}$ & $\begin{array}{c}\text { Owner } \\
\text { ship }\end{array}$ \\
\hline & \multicolumn{6}{|c|}{ Liaw \& Huang [20], No of Participants 168} \\
\hline SD & 3.63 & 2.74 & 4.03 & 3.43 & 4.09 & 3.14 \\
\hline \multirow[t]{2}{*}{ Mean } & 1.39 & 1.65 & 1.39 & 1.53 & 1.24 & 1.57 \\
\hline & \multicolumn{6}{|c|}{ Özdoğan, Başoğlu, \& Erçetin [24], No of Participants 81} \\
\hline SD & 4.27 & 4.05 & 3.4 & 3.85 & 3.63 & 3.95 \\
\hline \multirow[t]{2}{*}{ Mean } & 0.97 & 1.18 & 1.37 & 1.01 & 1.32 & 1.04 \\
\hline & \multicolumn{6}{|c|}{ Scornavacca, Huff, \& Marshall [26], No of Participants 569} \\
\hline SD & 4.04 & na & 4.05 & 3.71 & 2.95 & 3.67 \\
\hline \multirow[t]{2}{*}{ Mean } & 1 & na & 1.02 & 1.06 & 1.01 & 1.1 \\
\hline & \multicolumn{6}{|c|}{ Alzaza \& Yaakub [28], No of Participants 261} \\
\hline SD & 4.05 & na & 3.91 & 3.87 & 4.5 & na \\
\hline \multirow[t]{2}{*}{ Mean } & 0.63 & na & 0.66 & 0.76 & 0.81 & na \\
\hline & \multicolumn{6}{|c|}{ Seliaman \& Al-Turki [30], No of Participants 55} \\
\hline SD & na & 4.02 & $\mathrm{Na}$ & 4.12 & na & 4.01 \\
\hline \multirow[t]{2}{*}{ Mean } & na & 1.06 & $\mathrm{Na}$ & 0.66 & na & 0.71 \\
\hline & \multicolumn{6}{|c|}{ Motiwalla \&.Bruck [32], No of Participants 33} \\
\hline SD & 3.3 & 3.11 & $\mathrm{Na}$ & 2.43 & 2.49 & 3.97 \\
\hline \multirow[t]{2}{*}{ Mean } & 0.79 & 1.02 & $\mathrm{Na}$ & 1.15 & 1.16 & 1.07 \\
\hline & \multicolumn{6}{|c|}{ Cheon, Lee, Crooks, \& Song [35], No of Participants 177} \\
\hline SD & 3.72 & 3.9 & na & 3.48 & 3.71 & 3.71 \\
\hline \multirow[t]{2}{*}{ Mean } & 1.44 & 1.14 & na & 1.44 & 1.29 & 1.35 \\
\hline & \multicolumn{6}{|c|}{ Liu, Liu, \& Carlsson [36], No of Participants 219} \\
\hline SD & 3.8 & $\mathrm{Na}$ & na & 3.33 & na & 3.31 \\
\hline \multirow[t]{2}{*}{ Mean } & 1.24 & $\mathrm{Na}$ & na & 1.3 & na & 1.31 \\
\hline & \multicolumn{6}{|c|}{ Ju, Sriprapaipong, \& Minh [37], No of Participants 245} \\
\hline SD & 2.36 & $\mathrm{Na}$ & na & 2.19 & 2.38 & 2.23 \\
\hline Mean & 1.06 & $\mathrm{Na}$ & na & 1.16 & 1.12 & 1.16 \\
\hline
\end{tabular}

TABLE III. META ANALYSIS OF CSFS

\begin{tabular}{|c|c|c|c|c|c|c|}
\hline \multirow{2}{*}{ CSFs } & \multicolumn{6}{|c|}{ Meta Analysis Statistics } \\
\cline { 2 - 7 } & $\begin{array}{c}\text { No. } \\
\text { of } \\
\text { Studi } \\
\text { es }\end{array}$ & $\begin{array}{c}\text { No. of } \\
\text { Particip } \\
\text { ants }\end{array}$ & $\begin{array}{c}\text { Net } \\
\text { Mean }\end{array}$ & $\begin{array}{c}\text { Net } \\
\text { SD }\end{array}$ & $\begin{array}{c}\text { CSF } \\
\text { Rank }\end{array}$ & $\begin{array}{c}\text { Pearson } \\
\text { Corr. }\end{array}$ \\
\hline $\begin{array}{c}\text { Learner's } \\
\text { Perception }\end{array}$ & 9 & 1808 & 3.379 & 1.119 & NA & 1 \\
\hline $\begin{array}{c}\text { User Friendly } \\
\text { Design }\end{array}$ & 8 & 1753 & 3.646 & 1.065 & 3 & 0.92961 \\
\hline $\begin{array}{c}\text { Learner } \\
\text { Community } \\
\text { Development }\end{array}$ & 5 & 514 & 3.564 & 1.21 & 4 & 0.64153 \\
\hline $\begin{array}{c}\text { Technical } \\
\text { Competence }\end{array}$ & 4 & 1079 & 3.848 & 1.11 & 2 & -0.5595 \\
\hline Content & 7 & 1289 & 3.958 & 1.136 & 1 & 0.80454 \\
\hline Ownership & 8 & 1547 & 3.499 & 1.164 & 5 & 0.6064 \\
\hline
\end{tabular}

\section{RESULTS AND DISCUSSION}

The success of m-Learning is dependent on the views of the users of the m-Learning platform. The popularity of mobile phones in the present day world cannot be denied; neither can their increased invasion in all aspects of people's lives. Despite this, the use of mobile technology in the educational sector has been limited. As the popularity and the all-encompassing nature can be only due to the favorable user perception, it can be concluded that the users have certain reservations when it comes to the use of mobile technology in the educational sector. The objective of this paper is to assess the user's perceptions of what they consider as the key factor necessary for the successful adoption of mobile learning in educational institutions. We conducted a meta-analysis of the existing studies that evaluated the critical success factors of the mLearning platform. The results of the analysis are given in the Table III above.

The Table III shows aggregated results from the metaanalysis of 9 similar studies conducted measuring the critical success factors of mobile learning. The independent observation of the means shows the response tendency on a 5point Likert scale ( 1 - strongly disagree to 5 - strongly agree). This means that a mean over 2.5 means that learner agree that the factor has an appreciable influence on their current experience with the m-Learning platform. From the Table III, it can be seen that all the six CSFs have an aggregate response much over 2.5, showing that each of these factors have appreciable influence on their current experience with the $\mathrm{m}$ Learning platform.

The ranks of the means of the responses given in the Table III shows how much influence the factor has on the potential success of m-Learning, according to the learners. It is seen that content is considered to have the most influence, followed by technical competence of learners, user friendly design, learner community development and ownership.

The next step is to find if the factors are seen to positively affect the learner's perception of mobile learning. As discussed earlier, correlation of the CSFs with Learner's perceptions is a means of judging the success factors of m-Learning from the learner's perspective. Both content and user friendly design has highly positive correlations with learner's perception. This means that both good content and user friendly design of the content are essential to learners if they are to choose m- 
Learning platform in future. Ownership i.e. flexibility to use mLearning anytime, anyplace and Learner community development i.e. using m-Learning platform to connect with other learner or educators, are also positively related with learner's perception. This means that learner's view both these factors are also important. Interestingly technical competence is negatively correlated with learner's perception. This means that learner's consider that they already have technical capabilities (since mobiles are ubiquitous in the present day world), and so the factor is not critically important in their choice for selecting $\mathrm{m}$-Learning platform in future.

\section{CONCLUSION}

The aim of the present study was to develop an understanding of the critical success factors that affect the implementation of m-learning programs in higher education settings. A meta-analysis of multiple studies was conducted on the likes of the seminal 2006 study by Naismith and Corlett using updated data.

Some aspects such as technical competence of educators, development of assessment techniques and institutional support have been considered by very few studies as success factors. This does not mean that the factors are not important. It is in fact a possible explanation of the slow adoption of the technology in the education sector. As the researchers and in consequence the universities do not consider these aspects to be important, the learning initiatives are bound to be limited in success. This is a possible area of focus by future researchers. We are currently working on comprehensively surveying the CSFs for $\mathrm{m}$-Learning and other related disciplines such as $\mathrm{m}$ Health, m-Banking and m-Government will be investigated to prioritizing and classifying the CSFs into different groups such as: from students' perspective, from instructors' i.e. educators' perspective, from universities management's perspective, and technology capability, this would be promising to propose a new conceptual framework to comprehensively study and analyze the relationship between the CSFs in different countries.

\section{ACKNOWLEDGMENT}

The first author would like to thank the ministry of higher education in Saudi Arabia for his personal fund.

\section{REFERENCES}

[1] H. Väätäjä, A. Männistö, T. Vainio, and T. Jokela, "Understanding user experience to support learning for mobile journalist's work", R. Guy (Ed.) The Evolution of Mobile Teaching and Learning, California: Informing Science Press, 2009, pp. 177-210.

[2] T. Andrews, R. Smyth, B. Tynan, A. Berriman, D. Vale, and R. Cladine, "Mobile technologies and rich media: expanding tertiary education opportunities in developing countries", A.G. Abdel-Wahab and A.A.A. El-Masry (Eds.) Mobile Information Communication Technologies Adoption in Developing Countries: Effects and Implication, New York: Idea Group Inc. 2010.

[3] J. Paul and R. Seth, "Japan-India diplomacy and relationship marketing", Paul (Ed.) International Marketing - text and Cases, $2^{\text {nc }}$ edition, New Delhi: Tata McGraw-Hill Education, 2012, pp. 178-180.

[4] RFE/RL, (2012), "Report says 75 percent of world's population have mobile phones", July 17 2012, [Online], Available From http://www.rferl.org/content/report-says-75-percent-of-worldspopulation-have-mobile-phones/24648234.html [Accessed on 25 March 2013].
[5] T. Goh, "Mobile learning adoption: handover from technology to consumer", IEEE Learning Newsletter, vol. 14, Issue 1, January 2012, pp. 28-31

[6] L.H. Tsai, S.S.C. Young, and C.H. Liang, "Exploring the course development model for the mobile learning context: a preliminary study", Fifth IEEE International Conference on Advanced Learning Technologies ICALT05, 2005, pp. 5-8.

[7] P. Vate-U-Lan, "Mobile learning: major challenges for engineering education", $38^{\text {th }}$ ASEE/IEEE Frontiers in Education Conference, October 22-25, 2008, pp. 11-16.

[8] A. Ali, A. Ouda, L.F. Capretz, “A conceptual framework for measuring the quality aspects of mobile learning", Bulletin of the IEEE Technical Committee on Learning technology, vol. 14, No. 14, October 2012, pp. 31-34

[9] A. Saccol, J.L.V. Barbosa, E. Schlemmer, and N. Rienhard, "Corporate m-learning: applications and challenges", R. Guy (Ed.) Mobile Learning: Pilot Projects and Initiatives, California: Information Science, 2010

[10] A. Kukulska-Hulme and J. Taxler, "Designing for mobile and wireless learning”, H. Beetham and R. Sharpe, (Eds.) Rethinking Pedagogy for a Digital Age: Designing and Delivering e-Learning, London: Roultedge, 2007, pp. 180-192.

[11] M. Ally, "Mobile learning: transforming the delivery of education and training", Edmunton: Athabasca University press, 2009.

[12] A. Moura and A.A. Carvalho, "Mobile learning: using SMS in educational contexts", N. Reynolds and M. Turcsányi-Szabó (Eds.) Key Competencies in the Knowledge Society, World Computer Congress, Brisbane 2010, New York: Springer, pp. 281-291.

[13] T. Wilen-Daungenti, “.Edu technology: technology and learning environments in higher education", New York: Peter Lang, 2008.

[14] J.B. Ferreira, A.Z. Klein, A. Freitas, and E. Schlemmer, "Mobile learning: definition, uses and challenges", L. A. Wankel, P. Blessinger, Increasing Student Engagement and Retention Using Mobile Applications: Smartphones, Skype, and Texting Technologies, Bingley: Emerald Publishing Group, 2013, pp. 47- 83.

[15] L. Naismith and D. Corlett, "Reflections on success: a retrospective of the mLearn conference eeries 2002-2005", mLearn 2006 - Across Generations and Cultures, Banff, Canada, [Online], Available From http://hal.archives-ouvertes.fr/docs/00/19/73/66/PDF/Naismith-Corlett2006.pdf [Accessed on 25 March 2013].

[16] UNESCO, "UNESCO mobile learning week report", 12-16 December 2011, [Online], Available from http://www.unesco.org/new/fileadmin/MULTIMEDIA/HQ/ED/ICT/pdf/ UNESCO \%20MLW\%20report\%20final\%2019jan.pdf [Accessed on 25 March 2013].

[17] UNESCO, "UNESCO mobile learning week report", 12-16 December 2011, [Online], Available from http://www.unesco.org/new/fileadmin/MULTIMEDIA/HQ/ED/ICT/pdf/ UNESCO\%20MLW\%20report\%20final\%2019jan.pdf [Accessed on 25 March 2013].

[18] A. Booth, D. Papaioannou, and A. Sutton, "Approaches to successful literature review”, California: SAGE, 2012.

[19] K.K. Teoh, "An examination of critical success factors in the implementation of ePortfolios in universities", Journal of Academic Language \& Learning, vol. 5, No. 2, 2011, pp. A60-A72.

[20] S.S. Liaw and H.M. Huang, "Exploring learners' acceptance toward mobile learning", T. Teo (Ed.) Technology Acceptance in Education: Research and Issues, Sense Publishers, 2011, pp. 145-157.

[21] T.D. Cochrane, "Exploring mobile learning success", ALT-J, Research in Learning Technology, Association for Learning Technology ,vol. 18. No 2, July 2010, pp. 133-148.

[22] M.A. Hamdeh and A. Hamdan, "Using analytical hierarchy process to measure critical success factors of m-learning", European, Mediterranean \& Middle Eastern Conference on Information Systems Abu Dhabi, UAE, 2010.

[23] J.H. Huang and Y.R. Lin, "Elucidating user behavior of mobile learning: a perspective of the extended technology acceptance model", The Electronic Library, Emerald Publishing Group, vol. 25, No. 5 2007, pp. 585-598. 
[24] K.M. Özdoğan, N. Başoğlu, and G. Erçetin, "Exploring major determinants of mobile learning adoption", 2012 Proceedings of PICMET '12: Technology Management for Emerging Technologies, IEEE, 2012, pp. 1415-1423.

[25] J.H. Valk, A.T. Rashid, and L. Elder, "Using mobile phones to improve educational outcomes: an analysis of evidence from Asia", International Review of Research in Open and Distance Learning, vol. 11, No. 1, 2010, pp. 117-140.

[26] E. Scornavacca, S. Huff, and S. Marshall, "Mobile phones in the class: if you can't beat them, join them", Communications of the ACM, vol. 52, No. 4, April 2009, pp. 142-146.

[27] W.H. Wu, Y.C.J. Wu, C.Y. Chen, H.Y. Kao, C.H. Lin, and S.H. Huang, "Review of trends from mobile learning studies: a meta-analysis", Computers \& Education, Elsevier Ltd., 59, 2012, pp. 817-827.

[28] N.S. Alzaza, and A R. Yaakub, "Students' awareness and requirement of mobile learning in higher education environment", America Journal of Economics an Business Administration, 3(1),Science Publication, 2011, pp. 95-100.

[29] D. Phuangthong and S. Malisawan, "A study of behavioral for 3G mobile internet technology: preliminary researh mobile learning", Proceedings of the Second International Conference on e-Learning for Knowledge-Based Society, Bangkok, 2005, pp. 17-1-17.7.

[30] M.E. Seliaman and M.S. Al-Turki, "Mobile learning adoption in Saudi Arabia", World Academy of Science, Engineering and Technology, 69, 2012, pp. 391-293.

[31] P.A. Bruck, L. Motiwalla, and F.Foerster, "Mobile elarning with microcontent: a framework and evaluation", $25^{\text {th }}$ Cled e-Conference
eDependability: Reliable and Trustworthy eServices for the Future, 2012.

[32] L. Motiwalla, P.A. Bruck, "Adoption of a micro-learning system”, Tenth AIMS International Conference on Management, Austria, 2013, pp. 1001-1008.

[33] Y.S. Wand, M.C. Wu, and H.Y. Wang, "Investigating the determinants and age and gender differences in the acceptance of mobile learning", British Journal of Educational Technology, vol. 4, No. 1, 2009, pp. 92118.

[34] T. Cochrane and R. Bateman, "Reflections on 3 years of m-learning implementation (2007-2009)", Sheffield Hallam University Research Archive, 2010.

[35] J. Cheon, S. Lee, S.M. Crooks, and J. Song, “An investigation of mobile learning readiness in higher education based on the theory of planned behavior", Computer \& Education, Elsevier Ltd., 59, 2012, pp. 1054 1064

[36] Y.Liu, H. Liu, and C. Carlsson, "Factors driving the adoption of $\mathrm{m}$ learning: an empirical study", Computers \& Education, Elsevier Ltd., ,22, 2010, pp. 1211-1219.

[37] T.L. Ju, W. Sriprapaipong, and D.N. Minh, "On the success factors of mobile learning", 2010.

[38] F.H. Chanchary and S. Islam, "Mobile learning in Saudi Arabia prospects and challenges", vol. 4, No. 1, 2009.

[39] P. Ravesteyn and R. Batenburg, "Surveying the critical success factors of BPM-systems implementation", Business Process Management Journal, vol. 16, No. 3, 2010, pp. 492-507. 